\title{
Interaction, Structure, Social Presence, and Satisfaction in Online Learning
}

\author{
Mehmet Barış Horzum \\ Sakarya University, TURKEY
}

Received 2 January 2013; accepted 6 February 2014; published online first 29 March 2014

\begin{abstract}
There have been various studies about interaction, structure, social presence and satisfaction in online learning; however, there is not any research which represents the relationships among these concepts. The purpose of this paper is to examine the relationship among these variables. The population of the study is involved 205 university students who enrolled bachelor degree completion program at the Ankara University. Structural equation modeling was used to test hypothesizes. The results of this study indicated that there is a negative correlation between the course structure and interaction dimensions defined by Moore in transactional distance theory. Secondly, online students' social presence was predicted positively by interaction and negatively by course structure. Furthermore, online learning satisfaction was predicted positively by social presence. Students are most satisfied when their social presences are high in the online learning.
\end{abstract}

Keywords: Transactional distance, course structure, interaction, social presence, satisfaction.

\section{INTRODUCTION}

Internet is one of the most important technologies in today's information society. The use of distance education applications for online learning has been rising in parallel with the dramatic increase of internet usage. For instance, According to data released from Internet World Stats (July 2013), $45.7 \%$ of Turkey's population actively use internet. Additionally in 1997, colleges, universities and the companies brought into the first online learning applications and within the two years, $10 \%$ of the college and universities and $25 \%$ of the companies practiced the online learning programs. By the year of 2001, these percentages increased to $80 \%$ for college and university and $60 \%$ for companies (Lynch, 2002). In 2009, total number of online learners

Correspondence to: Mehmet Barıș Sakarya University Faculty of Education, Computer and Instructional Technology Department

Hendek, Sakarya, TURKEY.

Phone: +902642957161

Email: mhorzum@sakarya.edu.tr

doi: 10.12973/eurasia.2014.1324a reached to 5.6 million, which means that the increase was 2.4 million users from 2004 to 2009. Most of the online learners consist of undergraduate students (Allen \& Seaman, 2010). Online learning continues to be a major trend in education. This situation is similar in Turkey and in the other countries besides USA.

In the online learning, most of the content is delivered via internet (Allen \& Seaman, 2010). Therefore, giving prominence to only the technology by ignoring the educational aspects will not produce effective instructions. c) found that $30 \%$ to $50 \%$ of the students failed to complete the distance learning programs in which educational aspects were not taken in to notice. These results revealed a necessity to original distance education theories to find solutions to drop out rate of distance learning students and similar problems. One of them is Transactional Distance (TD) theory.

\section{THEORETICAL FRAMEWORK}

TD theory was developed originally by Moore (1991, 1993). TD is a "psychological and communication space, not a psychical space, to be crossed, a space of potential misunderstanding between 


\section{State of the literature}

- Student satisfaction in online learning is an import ant variable. The increase of student satisfaction in online learning will reduce the rate of students dro p out of online learning.

- If online learning students social presence increase, students will feel themselves as part of this learnin $g$ environment and increase their satisfaction.

- If we present an environment with more interactiv e and less structured, social presence of online lear ning students will directly and satisfaction indirectl $\mathrm{y}$ increase.

\section{Contribution of this paper to the literature}

- This study is carried out with the goal of determini ng the influence of interaction, structure and social presence on online learning student satisfaction.

- Results of this study reveal that online learning env ironment includes less structure and more interacti on directly affect to development of the social pres ence and indirectly satisfaction and also social pres ence directly affect satisfaction.

- This study suggests that design of online learning e nvironment according to the recommendations of Moore's TD theory.

the inputs of instructor and those of the learner" (Moore \& Kearsley, 2012).

TD is associated with interactive television by Bischoff, computer conference by Saba, Shearer and Force, computer by Gayol, audio conference and teleconference by Brenner, videoconference by Chen, Chen\& Willits and Jung, internet by Chen, Chen, Huang, Jung, Choi, Lim \& Leem, Zhang, Lowell and Sandoe, e-learning by Lemone, blended learning by Dron, Seidel \& Litten, Dron and Horzum (Horzum, 2011). It is seen the most that the theory of TD is associated with distance learning applications in the internet.

Garrison (2000) defines that the theory of TD is the most known and the most applied theory. Cicciarelli (2008) also emphasizes that online media trainer's express the theory of TD is the most important theory that is always utilized. Structure and dialog are the components of this theory. Dialog refers to two-way interaction and communication possibility of program (Moore \& Kearsley, 2012). Learner-teacher communication constitutes the dialogue or interaction (Moore, 1989), course structure refers to flexibility of the program in satisfying the students' needs (Moore \& Kearsley, 2012) and flexibility in access to course components (i.e.; Content, learning outcomes and activities, constitutes the structure). There is negative correlation between course structure and dialogue therefore; increased course structure decreases the dialogue; vice versa increase in the dialogue decrease the structure in distance education (Chen, 2001).

Although numerous studies represent the negative correlation between course structure and interaction (Demir Kaymak \& Horzum, 2013, Jung, Seonghee, Lim \& Leem, 2002; Hopper, 2000; Horzum, 2007, 2011), on the contrary, some other studies found that TD theory does not validate the structure component (Force, 2004; Gorsky \& Caspi, 2005; Kanuka, Collet \& Caswell, 2002; Lowell, 2004). As a result, these conflicting findings reveal out a necessity to examine the relationship between structure and dialogue in online learning.

\section{Social Presence}

Social presence (SP) is one of the most crucial components of the quality of online learning experience from the student perspective (Cobb, 2009; Shin, 2003). SP is a learner ability to project them socially and emotionally as 'real' people into a community of learners (Garrison, Anderson \& Archer, 1999: 94).

SP could be affected by the characteristics of the use of tools. Online interactive tool's usage increased SP positively (Chou \& Min, 2009; Joyce \& Brown, 2009; Mykota \& Duncan, 2007; Weinel, Bannert, Zumbach, Hoppe \& Malzahn, 2011; Wise, Chang, Duffy, \& del Vale, 2004). From this aspect, interaction and SP are considered directly related two variables (Murphy \& Rodríguez-Manzanares, 2008; Richardson \& Swan, 2003). Related literature showed that SP has a positive effect on online learner's satisfaction and achievement (Olpak \& Çakmak, 2009).

Although there has been some research which examined the relationship between the SP and interaction, few studies, however, have investigated the relationship between the structure and SP. Since the relationship between the interaction and $\mathrm{SP}$ is validated, this finding could postulate the relation between the structure and the SP.

\section{Satisfaction}

Satisfaction is emphasized to be one of the most important factors that determined the quality of online instruction (Allen \& Seaman, 2010; Garrison \& Cleveland-Innes, 2005; Moore \& Kearsley, 2012). Satisfaction can be defined as fulfillment and pleasure level of the students about different aspects of learning service which they received in an online learning program. From this aspect, satisfaction is a factor which could be directly affected by learning service components. Variety of the offered courses, quality of the instruction, academic support, library service, 
usability of web site, communication services, quality of the course materials, internet speed and students affair are some of the factors that affect the satisfaction.

Related literature about the satisfaction shows that there are kinds of factors that affect the satisfaction in online learning environments. Online learner satisfaction primarily related their ability to learn from online content, interact and communicate from others, and understand to needs for success (Palmer \& Holt, 2009). This finding features the structure component of the TD theory and reveals out the relation between the structure and the satisfaction (Lee, \& Rha, 2009; Murphy \& Rodríguez-Manzanares, 2008; Stein, Wanstreet, Calvin, Overtoom \& Wheaton, 2005; Horzum, 2007).

Interaction is another factor influences the satisfaction in online learning and it is positively related with satisfaction (Ali, Ramay \& Shahzad, 2011; Burgess, 2006; Jung, Seonghee, Lim \& Leem, 2002; Lee \& Rha, 2009; Murphy \& Rodríguez-Manzanares, 2008; Stein, Wanstreet, Calvin, Overtoom \& Wheaton, 2005). SP is another factor that affects the satisfaction in online learning environments. In the related literature, SP is one of the significant predictor of both satisfaction and perceived learning outcomes (Delfino \& Manca, 2007; Murphy \& Rodríguez-Manzanares, 2008; Swan \& Shih, 2005; Wise, Chang, Duffy, \& del Vale, 2004).

\section{Research Hypothesis}

Although there have been various studies about interaction, structure, SP and satisfaction, any study has not yet investigated the relationships between all of them all in one. From this aspect, the purpose of the study is to examine the relationships among online learning students' interaction, structure, SP and satisfaction. Following research hypothesis provided the framework for the study:

In online learning environment, interaction would be associated negatively with structure.

1) Interaction will have a significant relationship with SP.

2) Structure will have a significant relationship with SP.

3) Interaction will have a significant relationship with satisfaction.

4) Structure will have a significant relationship with satisfaction.

5) SP will have a significant relationship with satisfaction.

\section{METHODOLOGY}

Structural equation modeling (SEM) was used to develop an acceptable model based on relationship among four basic research variables (online learning interaction, structure, SP, and satisfaction) in this study. SEM is one of the statistical methods that show us to relationships among more than one independent and dependent variables (Ullman \& Bentler, 2003). Participants were consisted of 205 blended (most of the learning application through the online) learning university students. Ideal sample size for SEM is expressed as 150 or more people (Kline, 2011). Research data were collected by using an online questionnaire.

\section{Instrument}

Perception of Online Courses Scale (POCS): Interaction and course structure in the online learning environment was measured by POCS. POCS was developed by Huang (2000) to assess the online course perceptions, and it has four sub-dimensions: interaction, structure, autonomy, and social comfort. In this study, 5-point Likert-type 15 items, and two sub-dimensions (Interaction and Structure) were used. POCS was adapted to Turkish language by the researcher. POCS Turkish form's internal consistency coefficient was .83 and the test-retest was .85 . According to confirmatory factor analyzed results and Cronbach's alpha values POCS is a valid and reliably instrument. Detailed results are presented in the Appendix.

The Social Presence Scale (SPS): Participants' SP was measured by using SPS. SPS was developed by Gunawardena and Zittle (1997) to assess the SP in computer mediated conferences. Although SPS has 14 items in original form, in the study, 5-point Likert-type 11 items were translated and used. After translation, SPS was prepared as a structure including original item, translated item and proposed form and given to 3 educational technology experts for their opinion. After making all necessary adjustments, these 11 items were used in this study. SPS Turkish form's internal consistency coefficient was .95. Confirmatory factor analyze results reveal a good fit and they are presented in the Appendix.

The Satisfaction Scale (SS): The SS was developed by Gunawardena \& Zittle (1997) and SS contains 5point Likert-type nine items. SS was adapted to Turkish by the researcher and SS Turkish form's internal consistency coefficient was .95. Confirmatory factor analyzed results prove the construct validity of SS. These results are presented in the Appendix.

Participants and data collection: Participants were consisted of 205 university students who enrolled in İlahiyat Lisans Tamamlama (ILITAM) (online learning + two weeks face to face learning in one year) bachelor degree completion program at the Ankara University, Turkey (for detailed information see in htpp://www.ilitam.ankara.edu.tr). In this study, the 
scale applied on the internet and convenient sampling method was used for the selection of the working group. The survey's link was published on the forum of the students' learning management system. As a result, volunteer students filled the scale. 101 learners were on their first year and 104 were on their second year. 105 of the participants $(51.2 \%)$ were males and 100 of them $(48.8 \%)$ were females. While $12(5.8 \%)$ students felt insufficient about internet use, $193(94.2 \%)$ students felt sufficient. The age of the students ranged was from 20 to 47 years, the average $( \pm S D)$ being $30.74 \pm 6.39$ years for the entire sample.

\section{Procedure}

Students participation permission was obtained from Ankara University Distance Education Center where the students were officially enrolled the program. Data were collected by an online questionnaire so completion was anonymous. Pearson correlation, coefficient and structural equation modeling were utilized to determine the relationships among course structure, interaction, SP, and satisfaction. Maximum likelihood estimations were used in structural equation modeling. Analyses were performed by LISREL 8.54.

\section{DATA ANALYSIS AND RESULTS}

\section{Descriptive Data and Inter-correlation}

The results of means, standard deviations and correlations of this study represent a significant correlation between course structure, interaction, SP, and satisfaction. Interaction was found negatively correlated with the course structure $(\mathrm{r}=-.33)$. Findings of this study support the Hypothesis 1. SP correlated positively with the interaction $(\mathrm{r}=.26)$ and negatively with the course structure $(\mathrm{r}=-.27)$. This finding supports the Hypothesis 2 and 3. On the other hand, while course structure has a negative correlation with the students' satisfaction $(\mathrm{r}=-.14)$, interaction $(\mathrm{r}=.26)$ and SP $(\mathrm{r}=.60)$ have positive correlation with satisfaction. This finding supports the Hypothesis 4, 5 and 6.

\section{Structural Equation Modeling}

The research model was examined by structural equation modeling (SEM). Results of SEM analysis are presented in Figure 1. The model exhibited a good fit $(\chi 2 / \mathrm{df}=1.20, \mathrm{GFI}=.99, \mathrm{AGFI}=.99, \mathrm{CFI}=.98, \mathrm{NFI}$ $=.99$, IFI $=.99$, and RMSEA $=.020)$. Furthermore, interaction and structure accounted for $11 \%$ of the SP and $01 \%$ of the satisfaction variance, and SP accounted

Table 1. Mean, Standard Deviation and Correlations Among the Variables

\begin{tabular}{|c|c|c|c|c|}
\hline Variables & 1 & 2 & 3 & 4 \\
\hline 1. Satisfaction & - & & & \\
\hline 2. SP & $.60 * *$ & - & & \\
\hline 3. Structure & $-.14^{*}$ & $-.27 * *$ & - & \\
\hline 4. Interaction & $.20 * *$ & $.26 * *$ & $-.33 * *$ & - \\
\hline Mean & 26.81 & 36.37 & 11.60 & 33.64 \\
\hline Standard deviation & 9.66 & 10.68 & 6.01 & 8.22 \\
\hline
\end{tabular}
$* \mathrm{p}<.05$

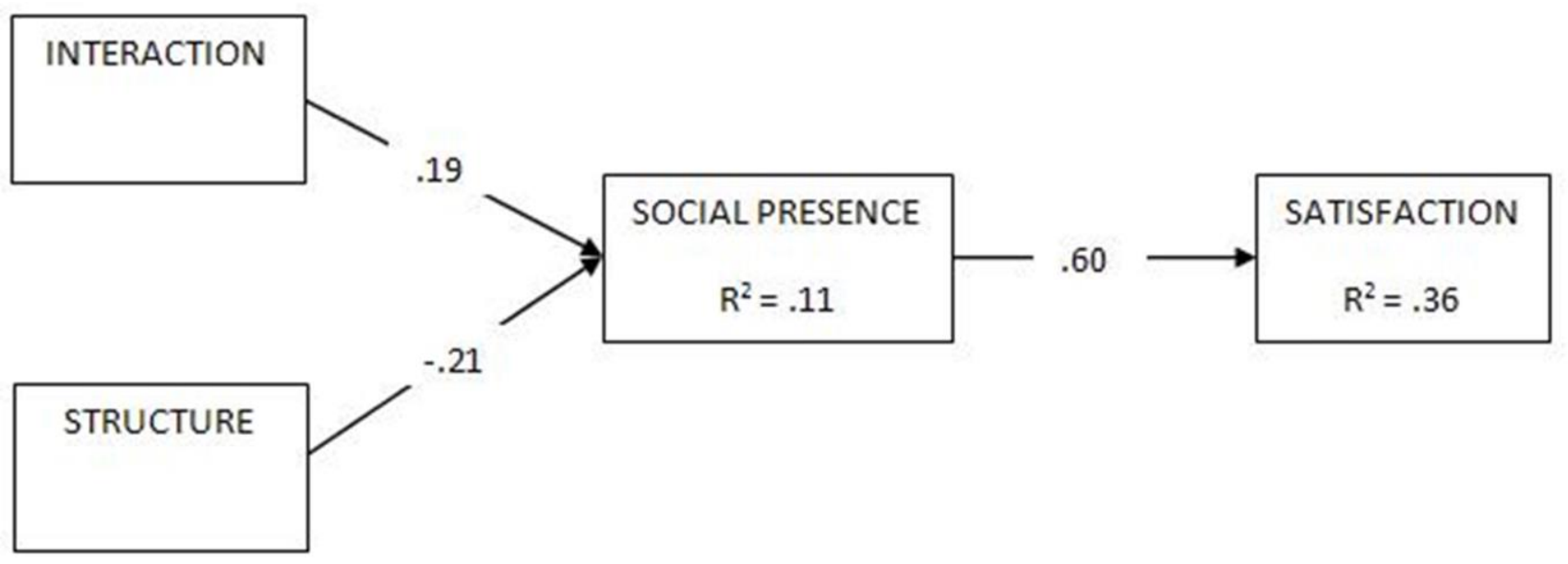

Figure 1. Path analysis between interaction, structure, SP, and satisfaction 
for $36 \%$ of the satisfaction variance.

The standardized coefficients in Figure 1 clearly showed that SP was predicted positively (.19) by interaction and negatively by course structure (-.21). In addition, satisfaction was explained positively by the SP (.60).

\section{DISCUSSION AND CONCLUSION}

Online learning has become one of the major distance learning trends for the last two decades (Allen \& Seaman, 2010). The need of research in the area of the online learning are emphasizes by many researchers (Lynch, 2002; Horzum \& Çakır, 2009). The purpose of this research was to investigate the relationships among the online learning satisfaction, SP, interaction and structure. Correlation and SEM result showed significant relationships among study variables. Indexes related to model was found to be in a good fit (Schermelleh-Engel, Moosbrugger \& Müller, 2003).

The findings obtained in this research represent a negative correlation between interaction and the course structure. It can be said that if the interaction between the online students and their teachers or classmate increase, the course structure may decrease. The results of this study is consistent with one of the TD theory's assumption which is course structure negatively correlated with the students' interaction, teacher and other students (Moore, 1991; 1993; Moore \& Kearsley, 2012; Sandoe, 2005). Similarly, this result is consistent with former studies results such as; Chen, 2001; Demir Kaymak \& Horzum, 2013, Jung, Seonghee, Lim \& Leem, 2002; Hopper, 2000; Horzum, 2007, 2011. The findings also showed that the course structure and interaction has a negative correlation.

However, some researches revealed that structure component of the theory do not validate (Force, 2004; Gorsky \& Caspi, 2005; Kanuka, Collet \& Caswell, 2002; Lowell, 2004). This can be the formation of different structures in different applications or sourced from different instructional design approaches.

Secondly, it was found that while the SP was predicted positively by interaction, it was predicted negatively by course structure. This means that the students' SP will be optimum in the online learning when course structure is low and interaction is high. This result is consistent with recent studies results (Chou \& Min, 2009; Joyce \& Brown, 2009; Murphy \& Rodríguez-Manzanares, 2008; Mykota \& Duncan, 2007; Richardson \& Swan, 2003; Weinel, Bannert, Zumbach, Hoppe \& Malzahn, 2011; Wise, Chang, Duffy, \& del Vale, 2004).

Finally, satisfaction was found to be predicted positively by the SP. This means students are most satisfied when their SP is high in the online learning. If teachers and developers create the SP in the distance learning systems, they should increase interaction between student teacher and classmate. This result is consistent with recent studies results (Delfino \& Manca, 2007; Murphy \& Rodríguez-Manzanares, 2008; Olpak \& Çakmak, 2009; Swan \& Shih, 2005; Wise, Chang, Duffy, $\&$ del Vale, 2004). Furthermore, the model of this study generates some indirect relationship between the variables. According to indirect results, satisfaction was correlated with interaction and course structure. These findings are also consistent with literature (Ali, Ramay \& Shahzad, 2011; Burgess, 2006; Jung, Seonghee, Lim \& Leem, 2002; Horzum, 2007; Lee, \& Rha, 2009; Murphy \& Rodríguez-Manzanares, 2008; Stein, Wanstreet, Calvin, Overtoom \& Wheaton, 2005).

The magnitude of them was neither interpreted nor discussed. If students satisfied with online learning, they should also provide them with the SP. If teachers and designers give the opportunity of SP in the online learning system, they should increase interaction between student and teacher, and also students-and students. Furthermore, teachers and designers should decrease the course structure in the online learning environment.

As a result, increasing dialogue and decreasing of structure have a positive-acting factor to the SP and satisfaction. This is one of the basic assumptions used in the shaping of Moore's theory. Besides this, decrease of structure has emerged as a required variable in addition to the dialogue. This finding is observed the confirmation of the other assumption that is "if structure increase dialogue decrease, or vice versa" Moore structured and underlined his theory which is the well-known and the most applied distance education theory (Cicciarelli, 2008; Garrison, 2000).

SP and motivation are the important variable for quality of the online learning (Cobb, 2009; Garrison \& Cleveland-Innes, 2005; Moore \& Kearsley, 2012; Shin, 2003). Based on the research findings, it is emphasized the importance for online learning that instructional designer must establish a balance between course structure and dialogue. Therefore, when designing online learning materials and systems, it should be taken to design interactive and less structured environments.

This study has some limitations, it is obviously gave some clues to provide direction for future research. Because the participants are online learners and their participation was voluntary; some of the online students did not accept to participate. So the number of the study group was decreased. In addition, since the study group consisted of only university students, research results are limited to bachelor degree completion learner and ILITAM system. Therefore, definitive statements cannot be used because of these limitations.

In the online learning environment there are many services offered by internet such as www, searching engines, e-mail, chatting/instant messaging programs 
and etc. Nowadays, services provided by the internet is based on the tools so-called Web 2.0. The effects of these Web 2.0 tool expressed as instruments of social interaction, with TD can be tested by using these tools in online learning environment. In the internet based education, designing the adaptive environments for students' individual differences has the character to affect the important variables such as students' achievement, self-efficacy, satisfaction, SP and TD. For this aspect, the effect of using adaptive environments by improving these for internet based learning is examined.

In conclusion, this study reports that online learner satisfaction with system affects SP directly, and interaction and course structure indirectly. Online student high SP, high interaction and low course structure increase the students' satisfaction in online learning environments. These findings shed light on the understanding of the online learner

\section{REFERENCES}

Ali, A., Ramay, M. I., \& Shahzad, M. (2011). Key factors for determining student satisfaction in distance learning courses: A study of Allama Iqbal Open University (AIOU) Islamabad, Pakistan. Turkish Online Journal of Distance Education-TOJDE, 12(2), 114-127.

Allen, I. E., \& Seaman, J. (2010). Learning on demand: Online education in the United States. Retrieved December 31, 2013, from http://sloanconsortium.org/publications/survey/ pdf/learningondemand.pdf.

Burgess, J. V. (2006). Transactional distance theory and student satisfaction with web-based distance learning courses. Unpublished doctoral dissertation, The University of West Florida.

Chen, Y. J. (2001). Transactional distance in World Wide Web learning environment. Innovations in Education and Teaching International Journal (IETI), 38(4), 327-338.

Chou, S. W., \& Min, H. T. (2009). The impact of media on collaborative learning in virtual settings: The perspective of social construction. Computers \& Education, 52(2), 417-431.

Cicciarelli, M. S. (2008). A description of online instructors use of design theory. International Journal of Information and Communication Technology Education, 4(1), 25-32.

Cobb, S. C. (2009). Social presence and online learning: A current view from a research perspective. Journal of Interactive Online Learning, 8(3), 241-254.

Delfino, M., \& Manca, S. (2007). The expression of social presence through the use of figurative language in a web-based learning environment. Computers in Human Behavior, 23, 2190-2211.

Demir Kaymak, Z., \& Horzum, M. B. (2013). Relationship between online learning readiness and structure and interaction of online learning students. Educational Sciences: Theory \& Practice, 13(3), 1783-1797.

Force, D. (2004). Relationships among transactional distance variables in asynchronous computer conferences: $A$ correlational study. Unpublished doctoral dissertation. Athabasca University, Athabasca, Alberta.
Garrison, D. R., \& Cleveland-Innes, M. (2005). Facilitating cognitive presence in online learning: Interaction is not enough. The American Journal of Distance Education, 19(3), 133-148.

Garrison, D. R., Anderson, T., \& Archer, W. (1999). Critical inquiry in a text-based environment: computer conferencing in higher education. The Internet and Higher Education, 2(2/3), 87-105.

Garrison, R. (2000). Theoretical challenges for distance education in the 21st century: A shift from structural to transactional issues. International Review of Research in Open and Distance Learning, 1(1), 1-17.

Gorsky, P., \& Caspi, A. (2005). A critical analysis of transactional distance theory. Quarterly Review of Distance Education, 6(1), 1-11.

Gunawerdana, C. N., \& Zittle, F. J. (1997). Social presence as a predictor of satisfaction within a computer-mediated conferencing environment. The American Journal of Distance Education, 11(3), 8-26.

Hopper, D. A. (2000). Learner characteristics, life circumstances, and transactional distance in a distance education setting. Unpublished doctoral dissertation, Wayne State University, Detroit, Michigan.

Horzum, M. B. (2007). Internet tabanle eğitimde etkilessimsel uzaklğ̆n ögrenci başarısi, doyumu ve öz-yeterlik algisina etkisi [The effect of transactional distance on students' achievement, satisfaction and self efficacy in internet based education]. Unpublished doctoral dissertation. Ankara University Educational Science Institute, Ankara.

Horzum, M. B., \& Çakır, Ö. (2009). Çevrim içi teknolojilere yönelik öz-yeterlik algısı ölçeği Türkçe formunun geçerlik ve güvenirlik çalışması [The validity and reliability study of the Turkish version of the online technologies self-efficacy scale]. Educational Sciences: Theory \& Practice, 9(3), 1327-1356.

Horzum, M. B. (2011). Developing transactional distance scale and examining transactional distance perception of blended learning students in terms of different variables. Educational Sciences: Theory \& Practice, 11(3), 1571-1587.

Huang, H. M. (2000). Moore's theory of transactional distance in an online mediated environment: student perception on the online courses. Unpublished doctoral dissertation, Seattle Pacific University, Seattle.

Internet World Stats (2013). Internet World Stats: Usage and Population Statistics. Retrieved January 07, 2014, from bttp:// www.internetworldstats.com/.

Joyce, K. M., \& Brown, A. (2009). Enhancing social presence in online learning: Mediation strategies applied to social networking tools. Online Journal of Distance Learning Administration, 12(4). Retrieved July 27, 2011, from http://www.westga.edu/ distance/ojdla/winter124/jo yce124 .html.

Jung, I., Seonghee, C., Lim, C., \& Leem, J. (2002). Effect of different type of interaction on learning achievement, satisfaction and participation in web based instruction. Innovation in Education and Teaching International, 39(2), 153-162

Kanuka, H., Collett, D., \& Caswell, C. (2002). University instructor perceptions of the use of asynchronous textbased discussion in distance courses. The American Journal of Distance Education, 16(3), 151-167. 
Kline, R. B. (2011). Principles and practice of structural equation modeling. New York: Guilford Press.

Lee, H. J., \& Rha, I. (2009). Influence of structure and interaction on student achievement and satisfaction in web-based distance learning. Educational Technology \& Society, 12(4), 372-382.

Lowell, N. O. (2004). An investigation of factors contributing to perceived transactional distance in an online setting. Published doctoral dissertation, University of Northern Colorado.

Lynch, M. M. (2002). The online educator: A guide to creating the virtual classroom. London: Routledge Falmer Taylor \& Francis Group.

Moore, M. G. \& Kearsley, G. (2012). Distance education: A systematic view of online learning ( $3^{\text {rd }} \mathrm{Ed}$.). Belmont, VA: Wadsworth Cengage Learning.

Moore, M. G. (1989). Three types of interaction. The American Journal of Distance Education, 3(2), 1-6.

Moore, M. G. (1991). Editorial: Distance education theory. The American Journal of Distance Education, 5(3), 1-6.

Moore, M. G. (1993). Theory of transactional distance. In D. Keegan (Ed.), Theoretical principle of distance education (p. 22-38). London: Routledge.

Murphy, E., \& Rodríguez-Manzanares, M. A. (2008). Revisiting transactional distance theory in a context of web-based high-school distance education. Journal of Distance Education, 22(2), 1-14.

Mykota, D., \& Duncan, R. (2007). Learner characteristics as predictors of online social presence. Canadian Journal of Education, 30(1), 157-170.

Olpak, Y. S., \& Kılıç Çakmak, E. (2009). E-öğrenme ortamları için sosyal bulunuşluk ölçeğinin uyarlama çalışması. Yü̃üncü Yal Üniversitesi, Eğitim Fakültesi Dergisi, IV(I), 142-160.

Palmer, S. R., \& Holt, D. M. (2009). Examining student satisfaction with wholly online learning. Journal of Computer Assisted Learning, 25(2), 101-113.

Richardson, J. C., \& Swan, K. (2003). Examining social presence in online courses in relation to students' perceived learning and satisfaction. Journal of Asynchronous Learning Networks, 7(1), 68-88.

Sandoe, C. (2005). Measuring transactional distance in online courses: The structure component. Unpublished doctoral dissertation. University of South Florida.

Schermelleh-Engel, K. Moosbrugger, H. \& Müller, H. (2003). Evaluating the fit of structural equation models: Tests of significance and descriptive goodness-of-fit measures. Methods of Psychological Research Online, 8(2), 2374.

Shin, N. (2003). Transactional presence as a critical predictor of success in distance learning. Distance Education, 24(1), 69-86.

Stein, D. S., Wanstreet, C. E., Calvin, J., Overtoom, C., \& Wheaton, J. E. (2005). Bridging the transactional distance gap in online learning environments. The American Journal of Distance Education, 19(2), 105-118.

Swan, K., \& Shih, L. F. (2005). On the nature and development of social presence in online course discussions. Journal of Asynchronous Learning Networks, 9(3), 115-136.

Ullman, J. B., \& Bentler, P. M. (2003). Structural equation modeling. In J. A. Schinka, \& W. F. Velicer (Eds.), Handbook of psychology, Volume 2. Research Methods in Psychology (pp. 607-634). Hoboken, NJ: John Wiley

Weinel, M., Bannert, M., Zumbach, J., Hoppe, H. U., \& Malzahn, N. (2011). A closer look on social presence as a causing factor in computer-mediated collaboration. Computers in Human Behavior, 27, 513-521.

Wise, E., Chang, J., Duffy, T., \& del Vale, R. (2004). The effects of teacher social presence on student satisfaction, engagement, and learning. Journal of Educational Computing Research, 31(3), 247-271. 
Appendix. Reliability coefficients and goodness of it indexes of confirmatory factor analyze of scales.

\begin{tabular}{|c|c|c|c|c|}
\hline Scale & Sub-Dimension & Reliability & Fit measure & Model value \\
\hline \multirow{8}{*}{ Perception of Online Courses Scale } & \multirow{5}{*}{ Interaction } & \multirow{5}{*}{0.95} & $\chi^{2} / \mathrm{df}$ & 2.52 \\
\hline & & & RMSEA & 0.067 \\
\hline & & & SRMR & 0.052 \\
\hline & & & CFI & 0.98 \\
\hline & & & NFI & 0.96 \\
\hline & \multirow{3}{*}{ Structure } & \multirow{3}{*}{0.94} & NNFI & 0.97 \\
\hline & & & GFI & 0.90 \\
\hline & & & AGFI & 0.89 \\
\hline \multirow{8}{*}{ SPS } & & \multirow{8}{*}{0.95} & $\chi^{2} / \mathrm{df}$ & 3.22 \\
\hline & & & RMSEA & 0.10 \\
\hline & & & SRMR & 0.041 \\
\hline & & & CFI & 0.97 \\
\hline & & & NFI & 0.98 \\
\hline & & & NNFI & 0.98 \\
\hline & & & GFI & 0.90 \\
\hline & & & AGFI & 0.85 \\
\hline \multirow{8}{*}{ Satisfaction Scale } & & \multirow{8}{*}{0.95} & $\chi^{2} / \mathrm{df}$ & 2.13 \\
\hline & & & RMSEA & 0.075 \\
\hline & & & SRMR & 0.027 \\
\hline & & & CFI & 0.99 \\
\hline & & & NFI & 0.99 \\
\hline & & & NNFI & 0.99 \\
\hline & & & GFI & 0.95 \\
\hline & & & AGFI & 0.90 \\
\hline
\end{tabular}

